\title{
MJMR EVALUATION OF DIETARY PROTEIN AND PHOSPHATE INTAKE AMONG THE HEMODIALYSIS PATIENTS WITH HYPERPHOSPHATEMIA IN PENANG, MALAYSIA
}

\author{
Su Mee Khor ${ }^{1}$, Angel Wei Ling Goh ${ }^{2}$, Chee Ping Chong* ${ }^{* 3}$ \\ ${ }^{\prime}$ Clinical Dietitian, Department of Dietary \& Food Service, Hospital Pulau Pinang, Penang, Malaysia. \\ ${ }^{2}$ Research Assistant, Discipline of Clinical Pharmacy, School of Pharmaceutical Sciences, Universiti \\ Sains Malaysia, Penang, Malaysia \\ ${ }^{3}$ Senior Lecturer, Discipline of Clinical Pharmacy, School of Pharmaceutical Sciences, Universiti Sains \\ Malaysia, Penang, Malaysia \\ *Corresponding Author's Email: jjueping@gmail.com
}

\begin{abstract}
Objective: High serum phosphate level and malnutrition are among the key factors that elevate the risk of mortality among hemodialysis patients. The objective of this study was to evaluate the total dietary protein and phosphate intake by hemodialysis patients with hyperphosphatemia in Penang state, Malaysia. Methods: This was a cross sectional study conducted between September to November 2015 which involved hemodialysis patients from eight dialysis centers in Penang. The inclusion criteria were hemodialysis patients aged more than 18 years old with serum phosphate more than $1.8 \mathrm{mmol} / \mathrm{L}$. Patients' two days' unscheduled diet recall that included one weekday and one weekend diet intake were recorded. Results: A total of 117 eligible hemodialysis patients were approached and 98 patients agreed to participate in this study. The mean age of the patients was $52.6 \pm 14.1$ years. The patients' mean serum phosphate and albumin level were $2.18 \pm 0.24 \mathrm{mmol} / \mathrm{L}$ and $38.28 \pm 3.94 \mathrm{~g} / \mathrm{L}$ respectively. The mean total dietary calorie intake was $1411.2 \pm 248.3$ $\mathrm{kcal} /$ day. Whereas, the mean dietary protein intake was $43.7 \pm 7.6 \mathrm{~g} /$ day and phosphate intake were $940.2 \pm 150.8 \mathrm{mg} / \mathrm{day}$. Conclusion: The dietary calories and protein intake for the hemodialysis patients were relatively low, indicating that the patients were at risk of malnutrition and mortality. The patients' dietary phosphate intake was within the recommended range, but the target serum phosphate level was not achieved.
\end{abstract}

\section{Keywords: Hemodialysis, Hyperphosphatemia, Dietaryprotein, Phosphate}

\section{INTRODUCTION}

The number of hemodialysis patients in Malaysia had increased by more than eleven folds over the past 20 years (Goh et al., 2014). Among these hemodialysis patients, only $15 \%$ of them achieved the targeted serum phosphate level of $0.8-1.3 \mathrm{mmol} / \mathrm{L}$ as recommended by KDIGO guideline (KDIGO CKD-MBD Work Group, 2009). There was only a slight improvement seen in the serum phosphate level of Malaysian hemodialysis patients with the mean of $1.8 \pm 0.5 \mathrm{mmol} / \mathrm{L}$ in 2005 as compared to $1.7 \pm 0.5 \mathrm{mmol} / \mathrm{L}$ in 2014 (Goh \& Ong, 2015). Generally, high phosphate level which is known as hyperphosphatemia, can lead to high risks of morbidity and mortality among the hemodialysis patients (Hruska et al., 2008). A previous study showed an increase of $6 \%$ of mortality rate with only 0.32 $\mathrm{mmol} / \mathrm{L}$ increase in serum phosphate (Block, 1998).
Besides the phosphate removal from dialysis and the use of phosphate binders, restriction of dietary phosphate also plays a crucial role to control the serum phosphate level among the hemodialysis patients. However, a previous study revealed that dietary restriction of phosphate may lead to poor nutritional status and survival among hemodialysis patients (Arenas et al., 2010). This is because dietary phosphate is usually origins from high protein diet. Hence, hemodialysis patients with restricted dietary phosphate consumption might have insufficient protein intake to prevent malnutrition.

Generally, the hemodialysis patients are recommended to consume dietary protein of $1.2 \mathrm{~g} / \mathrm{kg}$ body weight/day, which is higher than general population. This poses a major challenge for the successful rate in achieving the target serum phosphate level. In fact, a previous study 
conducted showed over half of hemodialysis patients had inadequate dietary protein intake of less than 1.0 $\mathrm{g} / \mathrm{kg} /$ day (Shinaberger et al., 2006). Despite the low protein intake, many hemodialysis patients had poorly controlled serum phosphate level. Poor adherence to phosphate binders (Chironda \& Bhengu, 2016) and hidden phosphate additives in diets (Benini et al., 2011) which were often overlooked by most of the medical practitioners became the challenges in maintaining the hemodialysis patients' target serum phosphate level.

The serum albumin level is an indicator to determine adequate dietary protein intake. According to the 22nd Report of the Malaysian Dialysis and Transplant Registry 2014, the percentage of hemodialysis patients who achieved desirable albumin level of more than 40 $\mathrm{g} / \mathrm{L}$ had reduced gradually from $56 \%$ to $41 \%$ between 2005 to 2014 (Goh \& Ong, 2015). This finding suggested that the Malaysian hemodialysis patients might have inadequate dietary protein intake. A previous study also showed a strong influence of protein intake with the serum albumin level (Sridhar \& Josyula, 2013). Despite having protein intake as an important indicator influencing the serum albumin level, inflammation is another factor contributing to hypoalbuminemia in hemodialysis patients. According to a study conducted by HEMO study group, sustained low serum albumin levels in hemodialysis patients was due to chronic inflammation in the patients (Kaysen et al., 2000).

There was a lack of Malaysian data evaluating the total dietary protein and phosphate intake among hemodialysis patients with hyperphosphatemia. Hence, this study was to evaluate the total dietary protein and phosphate intake by Malaysian hemodialysis patients. This study will gain better insights of the main causes of hyperphosphatemia among the hemodialysis patients and the potential interventions to control their serum phosphate level.

\section{METHODOLOGY}

This was a cross sectional study involving hemodialysis patients from eight dialysis centers in Penang state, Malaysia. Permissions to conduct the study was obtained from the Head of Department from Hospital Pulau Pinang, Hospital Seberang Jaya, Hospital Bukit Mertajam, Hospital Balik Pulau, Lion-NKF Dialysis Center, Buddhist Tzu Chi Merit Dialysis Center, FoyiNKF Hemodialysis Center and Foyi-NKF Unit 2
Hemodialysis Unit. The study was carried out from September 2015 to November 2015.

This study included end stage kidney disease patients age more than 18 years old undergoing routine hemodialysis treatment for at least 4 months prior to this study. The patients must have hyperphosphatemia with serum phosphate level more than $1.8 \mathrm{mmol} / \mathrm{L}$. Patients with major acute disease or psychological disorders were excluded from this study as they might have a significant lower dietary intake which will impact the total protein and phosphate intake.

All data collections were performed by the principal investigator who is a dietitian (the first author). Demographic information including age, gender, ethnicity, date started on dialysis, education level, weight, height, body mass index (BMI), serum phosphate level, and albumin level were collected on the first visit. The patients' two days' unscheduled 24 hours diet recall that included one weekday and one weekend were collected on the second and third visits. As a quick and convenient diet assessment instrument commonly used for research, 24 hours diet recall is a structured interview to capture the foods and beverages consumed by respondents in the past 24 hours, from midnight to midnight, on the day prior to the interview (Ma et al., 2009). The diet recall must be conducted on one weekday and one weekend because studies showed that the intakes were usually higher on weekends than weekdays (Lee \& Nieman, 2007).

The principal investigator personally collected face to face diet recall from each patient. Besides the description of the cooking methods, the time and venue of the reported food consumed by each patient were recorded in the recall. The details of snacks in between meals were also collected. The portion size was estimated with the help of visual aids (common household containers such as one bowl, one cup, one tablespoon and one teaspoon) during the diet recall interview. The patients were also asked during the recall if they had consumed their usual diet or retracted diet on the reported recalled day. The purpose of the 24-hour dietary data collection in this study was to estimate the total dietary protein and phosphate intake by the patients.

The data compilation and statistical analysis was performed by SPSS 18.0 for Window (SPSS Inc. Chicago, USA) statistical software package. All the 
continuous variable data was presented as percentage, mean and standard deviation. The total dietary protein and phosphate of the foods were calculated using the Nutrient Composition of Malaysia Food Book, 4th Edition (Tee, 1997) by the principle investigator.

The study was approved by the Medical Research \& Ethics Committee (MREC), Ministry of Health Malaysia (ethics approval number: NMRR-15-78225554) in September 2015. Considering ethical issues, verbal agreement to interview participant were done and a written consent form was signed by each participant prior to data collection.

\section{RESULTS}

A total of 384 hemodialysis patients were screened from eight dialysis centers. There were 117 hemodialysis patients who fulfilled the inclusion criteria of the study. However, only 98 patients from the 117 eligible hemodialysis patients agreed to participate and were enrolled in the study. There were 40 patients from government hospital dialysis centers and 58 patients from NGO dialysis centers. Majority of the patients had their hemodialysis done in Hospital Pulau Pinang $(20.4 \%)$ and Foyi-NKF Unit 2 Hemodialysis Unit (20.4\%) respectively. A significant number (19.4\%) of hemodialysis patients went to Buddhist Tzu Chi Merit Dialysis Center (Table 1).

Table 1: Distribution of hemodialysis patients from the dialysis centers

\begin{tabular}{|l|l|l|}
\hline No. & Dialysis centers & N (\%) \\
\hline & Hospital Dialysis Center & \\
\hline 1. & Hospital Pulau Pinang & $20(20.4)$ \\
\hline 2. & Hospital Seberang Jaya & $11(11.2)$ \\
\hline 3. & Hospital Bukit Mertajam & $5(5.1)$ \\
\hline 4. & Hospital Balik Pulau & $4(4.1)$ \\
\hline & NGO Dialysis Center & \\
\hline 1. & Foyi-NKF Unit 2 Hemodialysis Unit & $20(20.4)$ \\
\hline 2. & Buddhist Tzu Chi Merit Dialysis Center & $19(19.4)$ \\
\hline 3. & Foyi-NKF Hemodialysis Center & $12(12.2)$ \\
\hline 4. & Lion-NKF Dialysis Center & $7(7.1)$ \\
\hline & Total & $98(100.0)$ \\
\hline
\end{tabular}

The hemodialysis patients were mostly male $(68.4 \%)$ and were Chinese (70.4\%). Monday, Wednesday and
Friday were the most commonly visited dialysis days for the hemodialysis patients $(53.1 \%)$. Most patients $(62.2 \%)$ had been on hemodialysis for more than 5 years. A total of $59.2 \%$ of the patients had their education up to secondary school level while $60.2 \%$ of the patients were unemployed. The patients involved in this study had the mean age of $52.6 \pm 14.1$ years. The means weight and height of the patients were $60.7 \pm 10.8 \mathrm{~kg}$ and $1.6 \pm$ 9.0 meter, respectively. Even though the mean body mass index (BMI) was $23.1 \pm 3.5 \mathrm{~kg} / \mathrm{m} 2$, minority of the patients were under weight $(10.2 \%)$; whereas $43.9 \%$ and $45.9 \%$ respectively of patients were in normal weight and overweight (Table 2).

\section{Table 2: Patients' demographic characteristics}

\begin{tabular}{|l|l|}
\hline Characteristics & N (\%) \\
\hline Gender & \\
\hline Male & $67(68.4)$ \\
\hline Female & $31(31.6)$ \\
\hline Ethnic & \\
\hline Malay & $25(25.5)$ \\
\hline Chinese & $69(70.4)$ \\
\hline Others & $4(4.1)$ \\
\hline Dialysis Day & \\
\hline Monday/Wednesday/ Friday & $52(53.1)$ \\
\hline Tuesday/Thursday/ Saturday & $46(46.9)$ \\
\hline Years of dialysis ${ }^{\mathbf{a}}$ & \\
\hline 1 to 5 years & $37(37.8)$ \\
\hline More than 5 years & $61(62.2)$ \\
\hline Education level & \\
\hline Primary & $27(27.6)$ \\
\hline Secondary & $58(59.2)$ \\
\hline Diploma or higher & $13(13.2)$ \\
\hline Employment status & \\
\hline Yes & $39(39.8)$ \\
\hline No & $59(60.2)$ \\
\hline Body Mass Index, BMI (kg/m $\mathbf{m}^{\mathbf{b}} \mathbf{b}$ & \\
\hline$<18.5$ & $10(10.2)$ \\
\hline $18.5-22.9$ & $43(43.9)$ \\
\hline $23.0-27.4$ & $45(45.9)$ \\
\hline
\end{tabular}

${ }^{a}$ The Mean $\pm S D$ for years of dialysis is $6.9 \pm 4.2$ years

${ }^{b}$ The Mean $\pm S D$ for BMI is $23.1 \pm 3.5 \mathrm{~kg} / \mathrm{m} 2$ 
Considering the biochemical measures, $43.9 \%$ of the patients had serum phosphate level more than 2.2 $\mathrm{mmol} / \mathrm{L}$. A total of $57.2 \%$ patients had serum albumin level less than $40.0 \mathrm{~g} / \mathrm{L}$ (Table 3 ).

Table 3 Biochemical measures of the patients

\begin{tabular}{|l|l|}
\hline Blood test & N (\%) \\
\hline Serum Phosphate (mmol/L) & \\
\hline $1.8-2.2$ & $55(56.1)$ \\
\hline$\geq 2.2$ & $43(43.9)$ \\
\hline Total & $98(100.0)$ \\
\hline Serum Albumin $\mathbf{( g / L )})^{\mathbf{b}}$ & \\
\hline$<30.0$ & $1(1.0)$ \\
\hline $30.0-34.9$ & $18(18.4)$ \\
\hline $35.0-39.9$ & $37(37.8)$ \\
\hline$\geq 40.0$ & $42(42.9)$ \\
\hline Total & $98(100.0)$ \\
\hline
\end{tabular}

${ }^{a}$ The mean $\pm S D$ for phosphate level is $2.18 \pm 0.24 \mathrm{mmol} / \mathrm{L}$

${ }^{b}$ The mean $\pm S D$ for albumin level is $38.28 \pm 3.94 \mathrm{~g} / \mathrm{L}$

The mean protein intake of the patients was $0.75 \pm 0.19$ $\mathrm{g} / \mathrm{kg}$ body weight/day (43.7 $\pm 7.6 \mathrm{~g} /$ day) while the total dietary phosphate intake was $940.2 \pm 150.8 \mathrm{mg} /$ day. The mean total calories intake was $24.0 \pm 5.8 \mathrm{kcal} / \mathrm{kg}$ body weight/day (1411.2 $\pm 248.3 \mathrm{kcal} /$ day $)$.

The intake of high phosphate food by the hemodialysis patients during the past one year is illustrated in Table 4.

Table 4: Frequency of patients' high phosphate food intake

\begin{tabular}{|l|l|l|l|l|l|l|}
\hline Food Item & \multicolumn{5}{|l|}{ Number of patients, N (\%) } \\
\cline { 2 - 7 } & $\begin{array}{l}\mathbf{2 - 3} \text { times } \\
\text { per day }\end{array}$ & $\begin{array}{l}\text { Once per } \\
\text { day }\end{array}$ & $\begin{array}{l}\text { 2-4 times } \\
\text { per week }\end{array}$ & $\begin{array}{l}\text { 2-4 times } \\
\text { per month }\end{array}$ & $\begin{array}{l}\text { Few } \\
\text { once } \\
\text { once }\end{array}$ & Never \\
\hline Dairy product & $2(2.0)$ & $6(6.1)$ & $15(15.3)$ & $15(15.3)$ & $40(40.8)$ & $20(20.4)$ \\
\hline Processed meat & $0(0.0)$ & $0(0.0)$ & $9(9.2)$ & $18(18.4)$ & $39(39.8)$ & $32(32.7)$ \\
\hline Convenient food & $0(0.0)$ & $5(5.1)$ & $24(24.5)$ & $23(23.5)$ & $35(35.7)$ & $11(11.2)$ \\
\hline $\begin{array}{l}\text { Carbonated soft } \\
\text { drinks }\end{array}$ & $0(0.0)$ & $0(0.0)$ & $13(13.3)$ & $17(17.3)$ & $23(23.5)$ & $45(45.9)$ \\
\hline Seafood & $0(0.0)$ & $1(1.0)$ & $15(15.3)$ & $32(32.7)$ & $30(30.6)$ & $20(20.4)$ \\
\hline $\begin{array}{l}\text { Ready to bake } \\
\text { dough }\end{array}$ & $0(0.0)$ & $1(1.0)$ & $23(23.5)$ & $40(40.8)$ & $24(24.5)$ & $10(10.2)$ \\
\hline Biscuits & $1(1.0)$ & $11(11.2)$ & $54(55.1)$ & $11(11.2)$ & $15(15.3)$ & $6(6.1)$ \\
\hline Breads & $5(5.1)$ & $23(23.5)$ & $33(33.7)$ & $22(22.4)$ & $11(11.2)$ & $4(4.1)$ \\
\hline
\end{tabular}

From the eight groups of high phosphate foods, the biscuits and breads were mostly consumed by the patients. A total of $67.3 \%$ of the patients consumed biscuits and $62.3 \%$ consumed breads for at least 2 to 4 times per week. Besides, dairy products were also commonly consumed by $23.4 \%$ of the patients for at least 2 to 4 times weekly. However, there were also several food groups that were never being consumed by most of the hemodialysis patients. A total of $45.9 \%$ patients never took carbonated soft drinks such as CocaCola ${ }^{\circledR}$ and Pepsi ${ }^{\circledR}$. This was followed by $32.7 \%$ of the patients not consuming processed meats such as hotdog, burger, ham and nugget at all. About $20 \%$ of the patients did not consume both dairy products and seafood respectively while approximately $11 \%$ of the patients had never consumed convenient food such as instant noodles and premix 3-in-1 coffee powder throughout the past one year.

\section{DISCUSSION}

The hemodialysis patients in this study were found to have calorie and protein intake lower than the recommended intakes. The present study finding was consistent with a previous study conducted among 72 hemodialysis patients in Brazil on their nutritional status which also found low mean calories intake of $28 \pm 10$ $\mathrm{kcal} / \mathrm{kg} /$ day and protein of $0.9 \mathrm{~g} / \mathrm{kg} / \mathrm{day}$ (Pinto et al., 2009). The lack of sufficient protein and calorie intake among hemodialysis patients will cause malnutrition, eventually leading to higher morbidity and mortality rates (Ikizler \& Hakim, 1996). From the diet recall, the average calorie intake of the patients was only 24 $\mathrm{kcal} / \mathrm{kg}$ of body weight daily. It was relatively low as compared to the recommended intakes by the K/DOQI guideline (35 kcal/ $\mathrm{kg}$ body weight/day) (National Kidney Foundation, 2000). The same situation happened in the protein intake as well. All patients were found only consuming $0.74 \mathrm{~g} / \mathrm{kg}$ body weight/day of protein instead of a recommendation of $1.2 \mathrm{~g} / \mathrm{kg}$ body weight/day (National Kidney Foundation, 2000). Several studies have shown that low protein consumption below $0.9 \mathrm{~g} / \mathrm{kg}$ body weight/day will impair the survival of the hemodialysis patients. Instead, the highest survival for patients would be if the protein intake is between 1.0 and $1.4 \mathrm{~g} / \mathrm{kg}$ body weight/day (Fouque et al., 2011).

The hemodialysis patients in this study consumed about $940 \mathrm{mg}$ of dietary phosphate daily which was consistent with a previous Brazilian study reporting the patients' 
phosphate intake of $958 \pm 374 \mathrm{mg} /$ day (Fouque et al., 2011). The dietary phosphate intake in the present study was within the range as recommended by the K/DOQI guideline, which should be between $800-1000 \mathrm{mg} /$ day (adjusted for dietary protein needs) when the serum phosphorus levels are elevated more than $1.78 \mathrm{mmol} / \mathrm{L}$ in hemodialysis patients (National Kidney Foundation, 2000). There had been varies inconclusive debate about the dietary phosphate restriction or high protein diet would help in reducing the mortality rate in hemodialysis patients (Denomme \& Cui, 2013; Karavetian et al., 2014; Karkar, 2012; Waheed et al., 2013). Prescribing low dietary phosphate intake to the patients was learnt not bringing any survival benefit but in fact it might be harmful in long term period (Lynch et al., 2011). Instead, the phosphate restriction may cause protein malnutrition and inadequate caloric intake.

Ordinarily, the serum albumin level acts as one of the predictors for mortality rate in end-stage kidney disease patients that reflects the poor nutrition or malnutrition (Phelan et al., 2008). The mean albumin level of the patients in this study was $38.28 \mathrm{~g} / \mathrm{dL}$ which indicated poor nutrition. This finding was consistent to the mean serum albumin level that was reported in 22nd Report of the Malaysian Dialysis and Transplant Registry which showed $38.5 \mathrm{~g} / \mathrm{L}$ among the Malaysian hemodialysis patients in year 2014 . Only $41 \%$ of the hemodialysis patients in Malaysia achieved the normal albumin level $(>40.0 \mathrm{~g} / \mathrm{L}$ ). The percentage had dropped from $56 \%$ to $41 \%$ since 2005 , showing that the issue of malnutrition is getting worse in Malaysian dialysis patients (Goh \& Ong, 2015). Hence, the issue of malnutrition should be addressed promptly as previous studies have shown that serum albumin level less than $40.0 \mathrm{~g} / \mathrm{L}$ would contrarily and increasingly raise the mortality rate in hemodialysis patients (Lowrie \& Lew, 1990; Owen et al., 1993).

As hyperphosphatemia is a common complication faced by hemodialysis patients, restriction of dietary phosphate plays a crucial role in the management of hyperphosphatemia (Cannata-Andia \& RodriguezGarcia, 2002). Nevertheless, dietary restriction of phosphorus remained as a challenge to provide sufficient protein for malnutrition prevention because foods high in phosphorus are generally high in protein (Fouque et al., 2011). In fact, both hemodialysis treatment and phosphate binders were unable to remove all the dietary phosphate when the patients meet the requirement for calories and protein intake (GonzálezParra et al., 2012). Examples of foods or beverages that contain high amounts of phosphorus include meats, dairy products, dried beans, nuts, colas, peanut butter, and beer. Hemodialysis patients require a higher protein intake $(1.2 \mathrm{~g} / \mathrm{kg} /$ day) (National Kidney Foundation, 2000), making restriction of phosphorus even more challenging. Most patients in this study rarely consumed fast food, carbonated soft drink, and processed meats like hotdog, burger, ham or nuggets. However, the high phosphate food that were most frequently consumed by the hemodialysis patients were biscuits, breads, and convenient foods such as canned food, instant noodles and premix 3-in-1 coffee powder (contains coffee powder, creamer and sugar). Hemodialysis patients are more prone to consume convenient foods as these foods were easily accessible and cheaper than fresh and unprocessed healthy foods.

Currently, processed foods available in the market were often underestimated of their phosphate contents due to the addition of phosphate additive during the food processing. A previous study involving advanced kidney disease patients suggested that food additive found in most processed meat products might lead to higher serum phosphate level (Moe et al., 2011). The identification of the food additives remained as a challenge as the manufacturers did not require to list down the types and amount of phosphate salt used on the food label (Gutiérrez \& Wolf, 2010). For instance, similar cream crackers might have different types and amount of phosphate additive added depending on the formulating processes by the manufacturers. Product food labels with small prints containing an initial "E" followed by a number which serves as a code to distinguish food additives are often unnoticed by consumers. The E-Numbers are used to identify the phosphate substances found in specific food additives used by the food industry. The maximum permitted level of phosphates is ranged from $1000 \mathrm{mg}$ to $50,000 \mathrm{mg} / \mathrm{kg}$ in foods (European Food Safety Authority, 2013). Besides, some phosphate additives were only declared as "natural flavors" or "preservative" on the food label without identifying the additives. Therefore, these phosphate additives consumed by the patients could prevent them from achieving the target phosphate level even with less protein intake.

Generally, the phosphate additive in food has the highest 
bioavailability $(80 \%-100 \%)$ as compared to naturally present phosphate in the animal protein $(40-60 \%)$ and plant protein $(20-40 \%)$ rich food which is present in organic form. Organic phosphate in animal protein like poultry, fish, meat, and dairy products need to be hydrolyzed in the intestinal to transform into readily absorbable inorganic phosphate, leading to only 40$60 \%$ of the phosphate is absorbed by the intestinal (Noori et al., 2010). Meanwhile, plant proteins like grains, seeds, nuts, and legumes are mostly in the form of phytic acid or phytate. It is hardly split in the intestinal due to the lack of phytate enzyme in human body (Kalantar-Zadeh et al., 2010). Thus, despite the actual phosphate contents is high in plant protein, the lower rate of absorption has resulted less likely high phosphate burden compare to animal protein. A previous study revealed that taking more grain vegetarian diet gave better protein intake without affecting the phosphate level compared to meat diet (Moe et al., 2011).

The issue of hyperphosphatemia among hemodialysis patients can be controlled by several approaches. One of the crucial ways is to avoid consuming the processed foods that contain high phosphate (Moe et al., 2011). Instead, more grains vegetarian diet should be consumed to aid increase protein intake without adversely affecting the phosphate level. Besides, nutritional supplements which is high in calories and protein but low in phosphate should be recommended to the dialysis patients for achieving better nutritional status (Wolfson, 1999). Another strategy is to provide patient education on understanding the food labels to identify the content of phosphate additives. Additionally, manufacturers also play a vital role in implementing proper food labelling on phosphate additives.

\section{CONCLUSION}

The dietary calories and protein intake for the hemodialysis patients were relatively low as compared to recommended intakes. This insufficiency might pose higher risk of malnutrition and mortality among the patients. Even though the dietary phosphate intake among the hemodialysis patients was within the recommended range, the serum phosphate level was uncontrolled. Clinicians and other clinical team members should be aware of the nutritional care provision for hemodialysis patients to improve their health outcomes.

\section{ACKNOWLEDGEMENT}

The authors would like to thank the Director of Health Malaysia for permission to publish this paper.

\section{REFERENCES}

Arenas, M. D., Malek, T., Gil, M. T., Moledous, A., Alvarez-Ude, F. \& Reig-Ferrer, A. (2010) 'Challenge of phosphorus control in hemodialysis patients: a problem of adherence?', Journal of Nephrology, 23(5), pp. 525-534.

Benini, O., D'Alessandro, C., Gianfaldoni, D. \& Cupisti, A. (2011) 'Extra-phosphate load from food additives in commonly eaten foods: a real and insidious danger for renal patients', Journal of Renal Nutrition, 21(4), pp. 303-308.

Block, G. A., Hulbert-Shearon, T. E., Levin, N. W., \& Port, F. K. (1998) 'Association of serum phosphorus and calcium $\mathrm{x}$ phosphate product with mortality risk in chronic hemodialysis patients: a national study.', American Journal of Kidney Diseases, 31(4), pp. 607-617.

Cannata-Andia, J. B. \& Rodriguez-Garcia, M. (2002) 'Hyperphosphataemia as a cardiovascular risk factor -- how to manage the problem. ', Nephrology, Dialysis, Transplantation, 17(Suppl 11), pp. 16-19.

Chironda, G. \& Bhengu, B. (2016) 'Contributing Factors to Non-Adherence among Chronic Kidney Disease (CKD) Patients: A Systematic Review of Literature', Medical and Clinical Reviews, 2(4).

Denomme, J. \& Cui, W. (2013) 'The barriers surrounding hemodialysis for patients with ESRD: improving access since 1945', University of Western Ontario Medical Journal, 82(1), pp. 31-32.

European Food Safety Authority (2013) 'Assessment of one published review on health risks associated with phosphate additives in food', EFSA Journal, 11(11), pp. 3444.

Fouque, D., Pelletier, S. \& Guebre-Egziabher, F. (2011) 'Have Recommended Protein and Phosphate Intake Recently Changed in Maintenance Hemodialysis?', Journal of Renal Nutrition, 21(1), pp. 35-38.

Gafor, A. H. A., Koh, K. H., Karupaiah, T. \& Chee, W. S. S. (2014) $22^{\text {nd }}$ Report of the Malaysian Dialysis and Transplant Registry 2014, Kuala Lumpur, 
Malaysia: Malaysian Nephrology Society.

Goh, B. L., Ching, C. H., Kok, L. S., Liew, Y. F. \& Ganeshadeva, Y. M. (2014) $22^{\text {nd }}$ Report of the Malaysian Dialysis and Transplant Registry Kuala Lumpur,Malaysia: Malaysian Nephrology Society.

González-Parra, E., Gracia-Iguacel, C., Egido, J. \& Orti, A. (2012) 'Phosphorus and Nutrition in Chronic Kidney Disease', International Journal of Nephrology, 2012.

Gutiérrez, O. M. \& Wolf, M. (2010) 'Dietary Phosphorus Restriction in Advanced Chronic Kidney Disease: Merits, Challenges, and Emerging Strategies', Seminars in Dialysis, 23(4), pp. 401-406.

Hruska, K. A., Mathew, S., Lund, R., Qiu, P. \& Pratt, R. (2008) 'Hyperphosphatemia of chronic kidney disease', Kidney International 74(2), pp. 148-157.

Ikizler, T. A. \& Hakim, R. M. (1996) 'Nutrition in endstage renal disease', Kidney International 50(2), pp. 343-57.

Kalantar-Zadeh, K., Gutekunst, L., Mehrotra, R., Kovesdy, C. P., Bross, R., Shinaberger, C. S. \& Kopple, J. D. (2010) 'Understanding sources of dietary phosphorus in the treatment of patients with chronic kidney disease', Clinical Journal of the American Society of Nephrology, 5(3), pp. 519530.

Karavetian, M., Vries, N., Rizk, R. \& Elzein, H. (2014) 'Dietary educational interventions for management of hyperphosphatemia in hemodialysis patients: a systematic review and meta-analysis', Nutrition Reviews, 72(7), pp. 471-482.

Karkar, A. (2012) 'Modalities of hemodialysis: quality improvement', Saudi Journal of Kidney Diseases and Transplantation, 23(6), pp. 1145-1161.

Kaysen, G. A., Dubin, J. A., Müller, H. G., Rosales, L. M. \& Levin, N. W. (2000) 'The acute-phase response varies with time and predicts serum albumin levels in hemodialysis patients.', Kidney international, 58(1), pp. 346-352.

KDIGO CKD-MBD Work Group (2009) 'KDIGO clinical practice guideline for the diagnosis, evaluation, prevention, and treatment of Chronic Kidney Disease-Mineral and Bone Disorder (CKD-MBD)', Kidney International. Supplement, 113,pp. S1-S130.

Kok, L. S., Ghazalli, R. B., Ching, C. H., Fan, K. S. \& Liew, Y. F. (2013) 21th Report of the Malaysian Dialysis \& Transplant Registry, Kuala Lumpur, Malaysia: Malaysia Society of Nephrology.

Lee, R. D. \& Nieman, D. C. (2007) 'Measuring Diet', Nutritional Assessment. $6^{\text {th }}$ ed. New York: McGraw-Hill, pp. 80.

Lowrie, E. G. \& Lew, N. L. (1990) 'Death Risk in Hemodialysis Patients: The Predictive Value of Commonly Measured Variables and an Evaluation of Death Rate Differences Between Facilities', American Journal of Kidney Diseases, 15(5), pp. 458-482.

Lynch, K. E., Lynch, R., Curhan, G. C. \& Brunelli, S. M. (2011) 'Prescribed dietary phosphate restriction and survival among hemodialysis patients', Clinical Journal of the American Society of Nephrology, 6(3), pp. 620-629.

Ma, Y., Olendzki, B. C., Pagoto, S. L., Hurley, T. G., Magner, R. P., Ockene, I. S., Schneider, K. L., Merriam, P. A. \& Hebert, J. R. (2009) 'Number of 24-hour diet recalls needed to estimate energy intake', Annals of Epidemiology, 19(8), pp. 553559.

Moe, S. M., Zidehsarai, M. P., Chambers, M. A., Jackman, L. A., Radcliff, J. S. \& Trevino, L. L. (2011) 'Vegetarian compared with meat dietary protein source and phosphorus homeostasis in chronic kidney disease.', Clinical Journal of the American Society of Nephrology, 6(2), pp. 257-264.

National Kidney Foundation (2000) 'NKF-DOQI clinical practice guidelines for nutrition in chronic renal failure.', American Journal of Kidney Diseases, 35(Suppl 2), pp. 17-103.

Noori, N., Sims, J. J., Kopple, J. D., Shah, A., Colman, S., Shinaberger, C. S., Bross, R., Kovesdy, C. P. \& Kalantar-Zadeh, K. (2010) 'Organic and inorganic dietary phosphorus and its management in chronic kidney disease', Iranian Journal of Kidney Diseases, 4(2), pp. 89-100.

Owen, W. F. Jr, Lew, N. L., Liu, Y., Lowrie, E. G. \& Lazarus, J. M. (1993) 'The urea reduction ratio and serum albumin concentration as predictors of 
mortality in patients undergoing hemodialysis', The New England Journal of Medicine, 329(14), pp. 1001-1006.

Phelan, P. J., O'Kelly, P., Walshe, J. J. \& Conlon, P. J. (2008) 'The importance of serum albumin and phosphorous as predictors of mortality in ESRD patients.', Renal Failure, 30(4), pp. 423-429.

Pinto, D. E., Ullmann, L. S., Burmeister, M. M., Antonello, I. \& Pizzato, A. (2009) 'Associations between energy, protein, and phosphorus intakes in patients with chronic kidney disease on hemodialysis', Brazilian Journal of Nephrology, 31(4), pp. 269-276.

Shinaberger, C. S., Kilpatrick, R. D., Regidor, D. L., McAllister, C. J., Greenland, S., Kopple, J. D. \& Kalantar-Zadeh, K. (2006) 'Longitudinal associations between dietary protein intake and survival in hemodialysis patients', American Journal of Kidney Diseases 48(1), pp. 37-49.

Sridhar, N. R. \& Josyula, S. (2013) 'Hypoalbuminemia in hemodialyzed end stage renal disease patients: risk factors and relationships--a 2 year single center study', BMC Nephrology, 14, pp. 242.

Tee, E. S. (1997) Nutrient Composition of Malaysian Foods ( $4^{\text {th }} \mathrm{ed}$.). Kuala Lumpur: Institute for Medical Research.

Waheed, A. A., Pedraza, F., Lenz, O. \& Isakova, T. (2013) 'Phosphate control in end-stage renal disease: barriers and opportunities', Nephrology, Dialysis, Transplantation, 28(12), pp. 2961-2968.

Wolfson, M. (1999) 'Management of protein and energy intake in dialysis patients', Journal of the American Society of Nephrology, 10(10), pp. 2244-2247. 